\title{
Interest in Extra Curricular Activities and Self Efficacy of Senior Secondary School Students in Cross River State, Nigeria
}

\author{
Achi N. Bekomson ${ }^{1}$, Melvina N. Amalu ${ }^{1}$, Anthony N. Mgban ${ }^{1} \&$ Abang B. Kinsley ${ }^{1}$ \\ ${ }^{1}$ Department of Educational Foundations, University of Calabar, Calabar, Nigeria \\ Correspondence: Achi N. Bekomson, Department of Educational Foundations, University of Calabar, Calabar, \\ Nigeria. E-mail: achindifon@gmail.com
}

Received: February 26, 2020

doi:10.5539/ies.v13n8p79
Accepted: March 29, $2020 \quad$ Online Published: July 23, 2020

URL: https://doi.org/10.5539/ies.v13n8p79

\begin{abstract}
The main purpose of the study was to find out if interest in extra-curricular activities has any influence on self-efficacy with reference to social self-efficacy, academic self-efficacy, language self-efficacy and moral self-efficacy. The ex-post facto design was adopted for the study. A sample of 1,586 students was randomly selected from the public secondary schools in Cross River State for the study. A questionnaire titled "Interest in Extra Curricular Activity and Self-Efficacy (IECASEQ) was the instrument used for data collection. The face validity of the instrument was determined by two experts in test and measurement and two in educational psychology. The reliability of the instrument was determined using Cronbach Alpha reliability method. The data collected were analysed using descriptive statistics. The results revealed that interest in co-curricular activities significantly influenced social self-efficacy, academic self-efficacy, language self-efficacy, moral self-efficacy and overall self-efficacy. Based on the findings of this study, it was recommended among others that teacher and school administrators should create opportunities for students to travel for excursions, and not see involvement in co-curricular activities as a distraction to students.
\end{abstract}

Keywords: extra-curricular, activities, self-efficacy, senior, secondary, school, students

\section{Introduction}

The expectation of every parent and teacher is to see children do well academically, physically, socially, morally and otherwise. Recording academic success is not only based on the premise of hard work and determination, it also depends on the child's personal traits and characteristics needed for quality learning. One of the most important traits of a good learner is the belief in his capability and power to perform a given task. Unfortunately, the variance in students' self-efficacy reveals a downward prediction in their academic success. Though students have desires, they do not believe in their potentials to bring these desires to reality, and find it difficult to tackle challenging situations. Students with poor self-efficacy find it difficult to carry out advance extra-curricular activities because they lack confidence in themselves. Poor self-efficacy has over the years been observed by the researchers who are educators and classroom teachers, as being a worrisome trend of a high proportion of secondary school students in Cross River State, Nigeria. Observation in recent times has shown that students do not believe they are capable of performing academic responsibilities. They are poorly equipped and do not think they can face the complexities of routine activities in the school. Aspects of poor self-efficacy observed among students, include social self-efficacy, physical self-efficacy, academic self-efficacy, language self-efficacy and moral self-efficacy. Bekomson and Ntamu (2019) stated that most secondary school students find it difficult to recover their sense of efficacy after failing. The feeling of inadequacy make students procrastinate, while most of them without attempting, already feel that they are not capable of handling any given academic task. Poor self-efficacy has become a major threat to effective school learning. Bekomson and Mgban (2019) worried that students' lack of belief in their abilities could be the reason why they find it difficult to answer abstract questions during examination.

There has been a growing concern by researchers, psychologists, school counsellors, school administrators and parents who have over the years made several efforts to help students improve on their self-efficacy. Such notable efforts include establishing specific, short term goals in their curriculum and lessons to challenge the students. Some secondary schools organize extra lessons to help students learn more and have faith in themselves. Parents also organise extra-lessons for their children to equip them academically and make them feel capable to handle 
academic work, yet these efforts seem to yield little or no results. This situation prompted the current study.

Extra-curricular activities are organized interest building activities or skills that students' take part outside their basic academic lessons like sporting activities, music lessons, dancing/singing lessons, chorography, drama, debate, quiz etc. while self-efficacy according to Bandura (2000) is an individual's belief in his own ability to perform well, cutting across his feelings, thinking, behaviour and self-motivation. From the above definition, Burr (2012) contends that extra-curricular activities provide an environment for adolescent development of new skills and novel ideas that help them develop academic self-efficacy. He further argued that though the importance of extra-curricular activity is overwhelming for the development of academic self-efficacy, the child requires a moderate level of participation to boost self-efficacy, rather than a greater commitment that might encroach into the time for academic work.

The integration of interest in extra-curricular activities and self-efficacy in this study has revealed that the individual's perceived self-efficacy promotes the development of subsequent interest in topics and activities. Bandura (2000) reiterated that self-efficacy is constantly displayed from childhood to adulthood, and increases as an individual believes that he can accomplish a task. Self-efficacy can be reinforced during childhood by academic outcomes and athletic ability, public speaking, ability to sing or engage in other music related activities. Bandura (2000) believes that the best way one develops self-efficacy towards a particular task is by gaining mastery of the subject. When success is recorded, it results in the creation of additional success as one is likely to make another attempt.

Accordingly, various categories of extra-curricular activities ranging from music and art, academic extra-curricular organizations, students' unionism, school clubs and community groups provide different opportunities for adolescent growth, learning, and positive youth development (Burr, 2012). These diverse experiences as a result of participation in numerous forms of extra-curricular activities are associated with high academic self-efficacy. Broh (2002) argued that participation in extracurricular activities boost students' academic performance in three different ways. First, participation in extracurricular activities help students develop character and skills such as self-efficacy, self-esteem, positive work, perseverance, locus of control which are boosters of academic performance. Secondly, he maintained that involvement in extracurricular activities helps increase the social status of students and gives them opportunity to belong to leading crowd of peers, who are oriented towards academic work. Membership of such groups helps to promote students' self-efficacy and higher academic performance. Thirdly, interest in extracurricular activities creates a positive atmosphere for social interaction among students and the school, this situation fosters the development of social ties and social capital. Consequently, social ties create social control which enable students obey school rules, thus gain academic success.

Mahoney, Cairns, and Farmer (2003) conducted a longitudinal study and found that consistent involvement in extracurricular activities significantly relates to high interpersonal abilities, educational aspirations and status of students. Lewis (2004) reiterated that interest in extracurricular activities creates resilience as involvement in sporting activities outside school promotes self-discovery in students. This experience opens up new frontiers for the development of self-efficacy and school achievement. He added that involvement in extra-curricular activities motivate students to engage in team work. Marsh and Kleitman (2002) described a situation where students' devote more time involving in extra-curricular activities at the expense of their academic work, as zero-sum framework. They argue that involvement at the zero-sum produces an outright negative effect on academic activities. In this scenario, commitment to academic activities, athletics or social values are justifications for social status in school, which could be the reason why some students invest so much of their time to engage in extra-curricular activities, neglecting their school work. Amalu and Njoku stressed that academic satisfaction involves method of delivery of social activities that enhance learning.

Miller (2009) reported a negative relationship between extra-curricular activities and performance. According to him, the negative relationship was attributed to the lack of interest and preparedness displayed by athletes toward academic activities, which is why they recorded lower GPA's, lower persistence to graduation and lower chances of graduation. In a similar vein, Sander (2007) and Matthews and Ofobike (2006) reported a negative correlation between involvement in extra-curricular activities and performance in academics. In another report by Mahoney et al. (2003), extra-curricular activities were found to be related with academic achievement, social development and educational status of students. Sitkowski (2008) reports a link between involvement in extra-curricular activities and other life endeavours. He stated that extra-curricular activities play an important role in the development of intrinsic motivation, and self-efficacy, and how motivation promotes success academically (Coleman, 2006). Coleman (2006) reviewed adolescent culture to be characterized by a focus on cars, dates, sports, popular music, self-identity and other school related matters. In his study, he discovered that $70 \%$ of students especially boys 
would want to be remembered as star athletes while less than $30 \%$ wanted to be remembered as brilliant boys. This means that adolescent school culture seem to validate sports against academic success, which makes students who show interest in extra-curricular activities, more efficacious as they set goals and strive to achieve such goals through perseverance and resilience, toward sports activities (Coleman, 2006).

However, Stephens and Schaben (2002) found that students who involve in numerous extra-curricular activities in school recorded higher levels academic success, than those who got involved in one of such activities. They found a strong positive relationship between involvement in extra-curricular activities and self-efficacy, self-esteem, locus of control and involvement in other school activities. Their study also revealed that involvement in numerous extracurricular activities results in stronger positive, social and psychological characteristics, than involvement in only one extra-curricular activity. Stephens and Schaben (2002) believe that involvement in extracurricular activity is important for character building, discipline, self-esteem, mental alertness and social self-efficacy.

However, interest in extra-curricular activities according to Marsh and Kleitman (2002) help students identify with programmes meant to develop commitment to community values. It helps students to achieve good academic success, good course work selection, helps them attend to their homework articulately, and encourage educational aspirations of students. More so, Fredericks and Eccles (2006) found that involvement in extra-curricular activities is linked to positive academic outcomes with regard to improved grades, test scores, higher levels school engagement and improved educational aspirations. In the same vein, improved grade, higher levels school engagement and improved educational aspirations are antecedents that boost self-efficacy in children. Daley and Leahy (2003) carried out a study on involvement in extra-curriculum activities, using 126 students of about 8-9 years old, randomly drawn from a segment of students who were involved in at least one school organized extra-curricular activity. The second group of students who did not involve in extra-curricular activities was made up of 63 students. The result of the study revealed that students who took part in extra-curricular activities at a regular basis had a positive perception of themselves, and develop the habit of early school attendance, score better grades, develop higher self-concept which leads to high self-efficacy.

Olson (2008) discovered in his study that involvement in extra-curricular activities such as fine arts, significantly reduced the rate of absenteeism among students. Obviously, involvement in extra-curricular activities has recorded several benefits in students' school success. Students acquire some sort of mentoring and supportive relationships from adult role models. Identifying with supportive team leaders, help them to get more involved, get genuine interactions, constructive feedbacks, develop mutual trust and commitment (Logan \& Scarborough, 2008). In a similar development, Eccles (2003) discovered that involvement in extra-curricular activities such as performing arts, which cuts across school band, drama, and dance teams help students' achieve higher grade points and enjoy school. Eccles explored extra-curricular activities such as involvement in students' government, PEP clubs and cheerleading to be related with self-efficacy, as it is linked with self-identity and school attendance and achievement.

In a study carried out by Leung, $\mathrm{Ng}$, and Chan (2011) on co-curricular activities enhancing learning effectiveness of students, using a total of 575 students from "Association Degree Foundation Programme" and the "Associate Degree Programme" participated in the study in a Hong Kong based university, found that involvement in extra-curricular activities could not enhance students learning effectiveness, but found a relationship with self-efficacy on the experimental group only on the time factor. Invariably, this means that involvement in extra-curricular activities with reference to the study result may not also have any influence on the self-efficacy of students, since poor performance may likely produce poor self-efficacy. Chemers, Hu, and Garcia (2001), Zajacova, Lynch, and Espenshade (2005) supports this assumptions by describing learning effectiveness as the psychosocial factors affecting students'self-efficacy, and self-confidence. Nevertheless, Huang and Chang (2004), Stephens and Schaben (2002), Hunt (2005) argued that involvement in extra-curricular activities play an important role in students' academic success and overall competences through teams work. Fung, Lee, and Chow (2007) in line with the assertions of Huang and Chang (2004) reviewed a significant positive relation between students' involvement in extra-curricular activities and self-efficacy of students.

Banta (1998) carried out a longitudinal study following undergraduates through their college life, learning experiences, and adjustment in co-curricular activities at Virginia Commonwealth University (VCU). The results showed that an interface with people from diverse backgrounds made students more sociable, boosted the thinking abilities, and fine-tuned their ideas. This implies that positive social interaction produces high social self-efficacy and academic success. In a study by Kariyana, Maphosa, and Mapuranga (2012), to investigate the influence of learner's participation in school co-curricular activities on academic performance: Assessment of Educators' Perceptions. Using 40 teachers from both private and public schools found that involvement in extra-curricular activities motivates learners; build confidence and a positive attitude towards school work. They found that 
leadership positions assumed during extra-curricular activities, build up self-concept, and higher self-esteem. By implication, the building of confidence and self-esteem can only be actualized in individuals with high self-efficacy as this helps them belief in their capabilities to perform given task. Kariyana et al. (2012) in their study found that interest in involvement in extra-curricular activities, help them develop community spirit by encouraging social interaction. To support this finding. Hoffmann (2006) opined that involvement in extra-curricular activities offer students an opportunity for social interaction with peers and enhances development and growth. Eccles (2003) reiterated that involvement in extra-curricular activities promote academic achievement and social adjustment. However, Eccles (2003), Flanagan, Gill, and Gallay (2005), Busseri et al. (2006) reported that adolescents who involve in extra-curricular activities recorded higher levels of decision making skills, self-esteem, social trust and self-efficacy. Involvement in extra-curricular activities promotes positive youth's development through social interactions because of its intrinsic motivational properties (King et al., 2006; Larson, 2000). Involvement in extra-curricular activities helps children to develop confidence and problem solving abilities. It develops positive competencies, self-regulation, life satisfaction and self-efficacy and lower levels of anxiety (Gray, 2011; Larson, 2000; Mahoney, Schweder, \& Stattin, 2002; Richman \& Shaffer, 2000).

In a study among 3,328 Grade 7 students by Ma and Shek (2014) titled "prevalence and psychosocial correlates of after-school activities among Chinese adolescent in Hong Kong", it was reported that involvement in extra-curricular activities promoted positive youth development qualities, life satisfaction, positive adjustment, and social interaction. The implication of this is that the enhancement of positive developmental qualities, competence and social interaction is a good ground for the development of positive social self-efficacy. This assumption is supported by the views of Moore, Prescott, and Gardner (2008) who stated that involvement in extra-curricular activities contributes positively to interpersonal skills development, positive student interaction, and academic achievement. Ayoub, Fares, and Fares (2015) reported that involvement in extra-curricular activities is an avenue for students to refine their interpersonal skills, problem-solving skills, positive interpretation of events, reliance and social support.

\section{Research Methodology}

The research design for this study was the ex-post facto design. The research area for the study is Cross River State, Nigeria. It is one of the states in the South-South Geopolitical Zone of the Federal Republic of Nigeria. The population of the study consists of all the 38,514 Senior Secondary I and II Students (18,697 males and 19,817 females) spread across the 246 government secondary schools in Cross River State under the State Secondary Education board (S.S.E.B). The stratified random sampling technique was used for the study. The schools in the area were first stratified based on LGA and the researchers randomly selected $20 \%$ of the schools in each of the LGAs through hat and draw method (balloting). The sample used for this study consist of 1,529 students (663 males and 866 females) out of the initial 1,543 students randomly selected from 47 public secondary schools in Cross River State. A total of 802 students were selected from SS I classes and 741 students from SSII classes. The instrument used for data collection is a questionnaire titled "Interest in Co-curricular Activities, and Self-efficacy Questionnaire" (ICCASEQ). The questionnaire consists of three sections. Section A elicited from the respondents personal information, such as age and gender. Section B is designed with 6 items to measure interest in involvement in extra-curricular activities. While section $\mathrm{C}$ is designed with 24 items to measure self-efficacy, with four sub sections and six items to measure each sub variable of self-efficacy such as social self-efficacy, academic self-efficacy, language self-efficacy and moral self-efficacy. The scale is a four point Likert type. To ascertain the face validity, the topic, purpose of the study, research questions, research hypotheses and instrument were given to 4 professionals with specialty in Educational Psychology and test and measurement from the department of Educational Foundations, University of Calabar, Nigeria. To determine the reliability of the research instrument, a trial testing was done using fifty (50) students from three (3) secondary schools who did not take part in the actual study. Each sub-scale using Cronbach alpha approach yielded coefficient of .73.

\section{Procedure for Data Analyses}

Data collected from 1,529 subjects out of the initial sample of 1,543 selected for the study was used for the analyses while 14 copies of the instrument which was not properly filled were discarded. Simple percentages and bar graphs were used in responding to the research questions.

\section{Research Question}

How does interest in co-curricular activities influence self-efficacy of students.

To provide answers to this research question, simple percentages were used in matching levels of self-efficacy with their levels of interest in co-curricular activities. This was done in order to estimate the extent to which interest in co-curricular activities can influence students' self-efficacy. 
Table 1. Proportions subjects who were low, moderate and high in self-efficacy across interest in co-curricular activities

\begin{tabular}{|c|c|c|c|c|c|c|}
\hline $\mathrm{SN}$ & Variables & $\begin{array}{c}\text { Interest in } \\
\text { co-curricular } \\
\text { activities }\end{array}$ & $\begin{array}{l}\text { Low } \\
(\%)\end{array}$ & $\begin{array}{c}\text { Moderate } \\
(\%)\end{array}$ & $\begin{array}{c}\text { High } \\
(\%)\end{array}$ & $\begin{array}{l}\text { Total } \\
(\%)\end{array}$ \\
\hline \multirow{4}{*}{1.} & \multirow{4}{*}{ Social self-efficacy } & Low & 37.1 & 43.5 & 19.4 & 100 \\
\hline & & Moderate & 21.9 & 63.3 & 14.7 & 100 \\
\hline & & High & 32.8 & 49.7 & 17.5 & 100 \\
\hline & & Total & 26.1 & 58.0 & 15.9 & 100 \\
\hline \multirow{4}{*}{2.} & \multirow{4}{*}{ Academic self-efficacy } & Low & 32.2 & 46.1 & 21.7 & 100 \\
\hline & & Moderate & 25.4 & 60.0 & 14.6 & 100 \\
\hline & & High & 21.1 & 63.8 & 15.1 & 100 \\
\hline & & Total & 26.1 & 58.0 & 15.9 & 100 \\
\hline \multirow{4}{*}{3.} & \multirow{4}{*}{ Language self-efficacy } & Low & 23.6 & 69.4 & 6.9 & 100 \\
\hline & & Moderate & 27.2 & 56.3 & 16.5 & 100 \\
\hline & & High & 24.6 & 55.8 & 19.6 & 100 \\
\hline & & Total & 26.1 & 58.0 & 15.9 & 100 \\
\hline \multirow{4}{*}{4.} & \multirow{4}{*}{ Moral self-efficacy } & Low & 30.3 & 49.4 & 20.4 & 100 \\
\hline & & Moderate & 26.9 & 60.3 & 12.9 & 100 \\
\hline & & High & 18.6 & 60.2 & 21.2 & 100 \\
\hline & & Total & 26.1 & 58.0 & 15.9 & 100 \\
\hline \multirow{4}{*}{5.} & \multirow{4}{*}{ Overall self-efficacy } & Low & 45.3 & 43.0 & 11.6 & 100 \\
\hline & & Moderate & 24.6 & 59.9 & 15.5 & 100 \\
\hline & & High & 26.9 & 53.3 & 19.8 & 100 \\
\hline & & Total & 26.1 & 58.0 & 15.9 & 100 \\
\hline
\end{tabular}

The results as presented in Table 1 showed that, out of the subjects who had low level of social self-efficacy, 37.1 per cent, 43.5 per cent and 19.4 per cent respectively had low, moderate and high levels of interest in co-curricular activities, while out of the subjects who had moderate level of social self-efficacy, 21.9 per cent, 63.3 per cent and 14.7 per cent respectively had low, moderate and high level of interest in co-curricular activities, and out of the subjects who had high level of social self-efficacy, 32.8 per cent, 497 per cent and 17.5 per cent respectively had low, moderate and high level of interest in co-curricular activities.

The results also showed that out of the subjects who had low level of academic self-efficacy, 32.2 per cent, 46.1 per cent and 21.7 per cent respectively had low, moderate and high levels of interest in co-curricular activities, while out of the subjects who had moderate level of academic self-efficacy, 25.4 per cent, 60.0 per cent and 14.6 per cent respectively had low, moderate and high level of interest in co-curricular activities, and out of the subjects who had high level of academic self-efficacy, 21.1 per cent, 63.8 per cent and 15.1 per cent respectively had low, moderate and high levels of interest in co-curricular activities.

The results further show that out of the subjects who had low level of language self-efficacy, 23.6 per cent, 69.4 per cent and 6.9 per cent respectively had low, moderate and high levels of interest in co-curricular activities, while out of the subjects who had moderate level of language self-efficacy, 27.2 per cent, 56.3 per cent and 16.5 per cent respectively had low, moderate and high levels of interest in co-curricular activities, and out of the subjects who had high level of language self-efficacy, 24.6 per cent, 55.8 per cent and 19.6 per cent respectively had low, moderate and high level of interest in co-curricular activities.

Further examination of the results also show that out of the subjects who had low level of moral self-efficacy, 30.3 per cent, 49.4 per cent and 20.4 per cent respectively had low, moderate and high level of interest in co-curricular activities, while out of the subjects who had moderate level of moral self-efficacy, 26.9 per cent, 60.3 per cent and 12.9 per cent respectively had low, moderate and high levels of interest in co-curricular activities, and out of the subjects who had high level of moral self-efficacy, 18.6 per cent, 60.2 per cent and 21.2 per cent respectively had low, moderate and high levels of interest in co-curricular activities.

The results finally show that out of the subjects who had low level of overall self-efficacy, 45.3 per cent, 43.0 per cent and 11.6 per cent respectively had low, moderate and high levels of interest in co-curricular activities, while out of the subjects who had moderate level of overall self-efficacy, 24.6 per cent, 59.9 per cent and 15.5 per cent respectively had low, moderate and high levels of interest in co-curricular activities, and out of the subjects who 
had high level of overall self-efficacy, 26.9 per cent, 53.3 per cent and 19.8 per cent respectively had low, moderate and high levels of interest in co-curricular activities. The results are pictorially illustrated using bar graphs as shown in Figure 1 for visual impression.

SN $\quad$ Lariables

$(\%)$

1. Social self-efficacy

2. Academic self-efficacy

3. Language self-efficacy

4. Moral self-efficacy

5. Overall self-efficacy
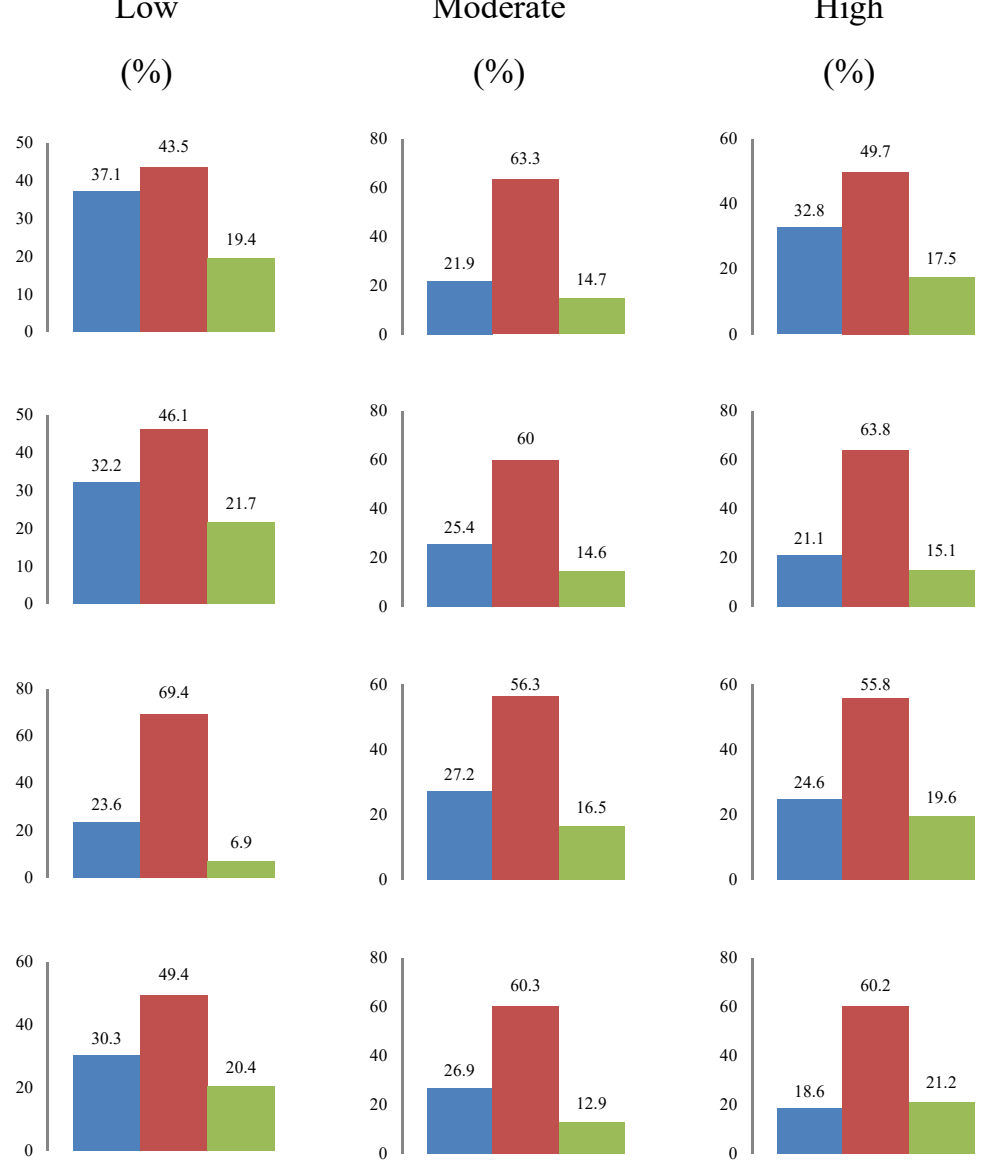

(\%)
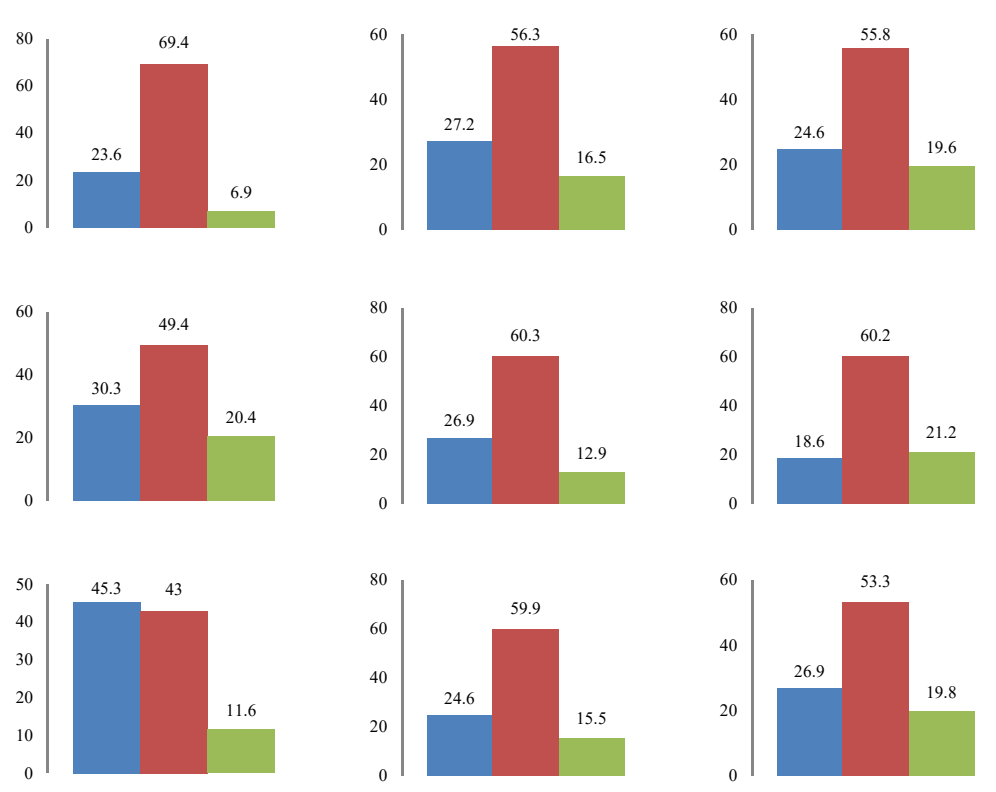

Key: Low High

Figure 1. Bar graphs pictorially illustrating the proportions of the respondents who were low, moderate and high in self-efficacy across interest in co-curricular activities

\section{Discussion of Findings}

Influence of interest in extra-curricular activities and self-efficacy:

The result of the research question revealed that the more the interest in extra-curricular activities, the better the subject's self-efficacy and vice versa. This can be attributed to the fact that when students are properly informed about the benefits of extra-curricular activities, and are given the opportunity to travel for excursions, they will definitely know how best to manage and channel their energy towards building self-efficacy. Students will appreciate and desire to take part in other extra-curricular activities rather than engaging in reading and writing alone.

The result of the present study also revealed that interest in extra-curricular activities significantly influence all the 
aspects of self-efficacy examined. Students who involve in extra- curricular activities are likely to make new friends and socialize easily. The fact that students meet different people during extra- curricular activities, it is assumed that they get exposed to interpersonal development skills as they meet new friends with diverse cultural affinities and language. Their ability to develop and maintain relationships could be responsible for the high self-efficacy revealed. Interest in extra- curricular activities is revealed to have an influence on academic self-efficacy, probably because taking part in interesting physical activities, results in mental alertness of students. Students' involvement in inter-school competitions exposes them to a wide range of information and knowledge that could make them feel efficacious in diverse ways of life, including their academics.

The outcome of the result could be that interest in extra-curricular activities, creates an avenue for the children to interact with other students and instructors from within and outside the school, who by way of interaction would positively affect their vocabulary and expose them to the understanding of many other languages.

The researchers assume that interest in extra-curricular activities could have had a significant influence on the self-efficacy of students, probably because from the home, as students set off to embark on any given sports activity, most parents are likely by way of advice tell their children to be of good behaviour, avoid activities and actions that could morally jeopardise the aim of the exercise. Another assumption could be that, the school management and teachers, who are always in the company of students during sporting activities are likely to sound as a way of warning that students must be of good behaviour, when taking part in extra- curricular activities, in other not to bring a bad reputation to the school.

The findings of the present study corresponds with the findings of Marsh and Kleitman (2002), Beghetto (2006) who reported that involvement in extra-curricular activities significantly influence academic self-efficacy of students. The findings of Coleman (2006), Stephens and Schaben (2002), and Fredericks and Eccles (2006) agree with the present study that involvement in extra-curricular activities significantly influence academic self-efficacy of students. Kelepolo (2011) and Mahoney et al. (2003) agreed with the findings of the present study by revealing that involvement in extra-curricular activities was greatly related to academic performance. Miller (2009), Sander (2007), and Matthews and Ofobike (2006) disagreed with the present study. Their findings revealed that involvement in extra-curricular activities could not enhance students' learning effectiveness. They revealed that students who dedicate interest and time involving in extra-curricular activities neglect their academic activities and consequently perform poorly. However, Foreman (2012) supports the present study. His findings revealed that involvement in extra-curricular activities promote positive youth development qualities, leadership development, improved social interaction and academic performance.

\section{Conclusion}

Interest in extra-curricular activities has a significant influence on social self-efficacy, academic self-efficacy, language self-efficacy, moral self-efficacy and overall self-efficacy. It was concluded that interest in co-curricular activities significantly influence social self-efficacy, academic self-efficacy, language self-efficacy, and moral self-efficacy.

\section{Recommendation}

It was recommended that Parents, teachers and school administrators should create opportunities for students to travel for excursions, and not see involvement in extra-curricular activities as a distraction to students.

\section{References}

Amalu, M. N., \& Njoku, J. N. (2019). Academic Self-Efficacy, Satisfaction and Academic Adjustment of Undergraduates in University of Calabar, Cross River State. International Journal of Pedagogy, Policy and ICT in Education, 7, 1-19.

Ayoub, F., Fares, Y., \& Fares, J. (2015). The psychological attitude of patients toward health practitioners in Lebanon. Journal of Medical Science, 7, 451-458. https://doi.org/10.4103/1947-2714.168663

Bandura, A. (2000). Exercise of human agency through collective efficacy. Current Directions in Psychological Science, 9, 75-78. https://doi.org/10.1111/1467-8721.00064

Banta, T. W. (1998). A missing link in assessment. Change, 30(2), 40-46. https://doi.org/10.1177/0149206311410606

Beghetto, R. A. (2006). Creative self-efficacy: Correlates in middle and secondary students. Creativity Research Journal, 18, 447-457. https://doi.org/10.1207/s15326934crj1804_4

Bekomson, A. N, \& Mgban, T. (2019). Interest in social interaction and self-efficacy among secondary school students in Cross River State. International Journal of Scientific Research in Education, 12(2), 231-239. 
https://doi.org/10.4314/gjedr.v18i2.4

Bekomson, A. N., \& Ntamu, B. A. (2019). Religious value orientation and self-efficacy among secondary school students in cross River State, Nigeria. Global Journal of Educational Research, 18(2), 81-89. https://doi.org/10.4314/gjedr.v18i2.4

Broh, B. A. (2002). Linking extra-curricular programming to academic achievement: Who benefits and why? Sociology of Education, 75(1), 69-95. https://doi.org/10.2307/3090254

Burr, B. L. (2012). Do extra-curricular activities help adolescents develop academic self-efficacy? Evidence of how and why (A Master's thesis). Retrieved from http://scholarschive.byu.edu/etd

Busseri, M. A., Rose-Krasnor, L., Willoughby, T., \& Chalmers, H. (2006). A longitudinal examination of breadth and intensity of youth activity involvement and successful development. Developmental psychology, 42(6), 1313. https://doi.org/10.1037/0012-1649.42.6.1313

Chemers, M. M., Hu, L. T., \& Garcia, B. F. (2001). Academic self-efficacy and first year college student performance and adjustment. Journal of Educational psychology, 93(1), 55. https://doi.org/10.1037/0022-0663.93.1.55

Coleman, J. S. (2006). The Adolescent Society: James Coleman's Still-Prescient Insights. Education Next, 6(1), 40-43.

Daley, J. A. \& Leadhy, J. (2003). Self-perceptions and participation in extra-curricular physical activities. The Physical Educator, 60(2), 13-19.

Eccles, J. (2003). Extra-curricular activities and adolescent development. Journal of Social Issues, 59(4), 865-889. https://doi.org/10.1046/j.0022-4537.2003.00095.x

Flanagan, C., Gill, S. \& Gallay, L. S. (2005). Social participation and social trust in adolescence: The importance of heterogeneous encounters. In A., Omoto (Eds.), Social participation in process of community change and social action. The Claremont Symposium on Applied Social Psychology.

Foreman, E. A. (2012). Undergraduate involvement in extra-curricular activities and leadership development in College of Agriculture and life science students. Journal of Agricultural Education, 53(3), 111-123. https://doi.org/10.5032/jae.2012.03111

Fredericks, J. A., \& Eccles, J. S. (2006). Is extracurricular participation associated with beneficial outcomes? Concurrent and longitudinal relations. Developmental Psychology, 43(4), 698-713. https://doi.org/10.1037/0012-1649.42.4.698

Fung, D., Lee, W., \& Chow, C. (2007). A feasibility study on personal development planning process embedded at the 'Special'ePortfolio for generic competencies development. European Institute for E-Learning (EIFEL), 332-340.

Gray, P. (2011). The decline of play and the rise of psychopathology in children and adolescents. American $\begin{array}{lllll}\text { Journal of } & \text { Play, } & \text { Retrieved } & \text { 443-463. } & \text { from }\end{array}$ http://www.psychologytoday.com/files/attachments/1195/ajp-decline-play-published.pdf

Hoffmann, J. P. (2006). Extracurricular activities, athletic participation, and adolescent alcohol use: Gender-differentiated and school-contextual effects. Journal of health and social behavior, 47(3), 275-290. https://doi.org/10.1177/002214650604700306

Huang, Y. R., \& Chang, S. M. (2004). Academic and co-curricular involvement: Their relationship and the best combinations for students' growth. Journal of College Students' Development, 45(4), 391-406. https://doi.org/10.1353/csd.2004.0049

Hunt, D. H. (2005). The effects of extracurricular activities in the educational process: Influence on academic outcomes. Sociological Spectrum, 2, 417-445. https://doi.org/10.1080/027321790947171

Kariyana, I., Maphosa, C., \& Mapuranga, B. (2012). The Influence of Learners' Participation in School Co-curricular Activities on Academic Performance: Assessment of Educators' Perceptions. Journal of Social Sciences, 33(2), 137-146. https://doi.org/10.1080/09718923.2012.11893093

Kelepolo, E. N. (2011). The relationship between participation in extracurricular activities and Utah's proficiency assessment of students in sub-urban school district. UNI-V. Theses, Dissertations, Professional Papers, and Capstones. Retrieved from http://digitalscholarship.univ.edu/thesesdisertations/1314/

King, G., Law, M., Hanna, S., King, S., Hurley, P., Rosenbaum, P., ... \& Petrenchik, T. (2006). Predictors of the 
leisure and recreation participation of children with physical disabilities: a structural equation modeling analysis. Children's Health Care, 35(3), 209-234. https://doi.org/10.1207/s15326888chc3503_2

Larson, R. W. (2000). Toward a psychology of positive youth development. American psychologist, 55(1), 170. https://doi.org/10.1037/0003-066X.55.1.170

Leung, C. H., Ng, C. W. R., \& Chan, P. O. E. (2011). Can Co-Curricular Activities Enhance the Learning Effectiveness of Students?: An Application to the Sub-Degree Students in Hong Kong. International Journal of Teaching and Learning in Higher Education, 23(3), 329-341.

Lewis, C. P. (2004). The relation between extracurricular activities with academic and social competencies in school age children: A meta-analysis (Doctoral dissertation). Retrieved from http://hdl.handle.net/1969.1/2710

Logan, W. L. \& Scarborough, J. L. (2008). Connections through clubs: Collaboration and coordination of a school wide program. Professional School Counselling, 12(2), 157-161. https://doi.org/10.5330/psc.n.2010.12.157

Ma, C., \& Shek, D. T. L. (2014). Prevalence and psychosocial correlates of after-school activities among Chinese adolescents in Hong Kong. Frontiers in public health, 2, 159.

Mahoney, J. L., Cairns, B. D., \& Farmer, T. W. (2003). Promoting interpersonal competence and educational success through extracurricular activity participation. Journal of educational psychology, 95(2), 409. https://doi.org/10.1037/0022-0663.95.2.409

Mahoney, J. L., Schweder, A. E., \& Stattin, H. (2002). Structured after-school activities as a moderator of depressed mood for adolescents with detached relations to their parents. Journal of Community Psychology, 30, 69-86. https://doi.org/10.1002/jcop.1051

Marsh, H. W., \& Kleitman, S. (2002). Extra-curricular school activities: The good, the bad and the nonlinear. Harvard Educational Review, 72(4), 464-511. https://doi.org/10.17763/haer.72.4.051388703v7v7736

Matthews, F. J., \& Ofobike, I. (2006). Panel Discusses Exploitation, Academic Prejudice Against Student-Athletes. Diverse Issues in Higher Education, 23(1), 8.

Miller, M. (2009). The impact of participation or non-participation in the academic excellence commitment areas of the NCAA Champs/life skills programme on the academic progress and graduation success rate of division I football teams (Unpublished Doctoral Dissertation). Old Dominion University, Norfolk: V. A.

Olson, C. A. (2008). Can music education help at-risk students? Study finds positive testimony substantial but quantitative research lacking. Teaching Music, 16(3), 20. Retrieved from http://www.menc.org

Richman, E. L., \& Shaffer, D. R. (2000). If you let me play sports: How might sports participation influence the self-esteem of adolescents females? Psychology of Women Quarterly, 24, 189-199. http://doi.org/10.1111/j.1471-6402.2000.tb002000.x

Sander, L. (2007). Graduation rates of athletics outpace students at large. The Chronicle of Higher Education, 54(11), 1-8.

Sitkowski, L. S. (2008). The effects of participation in athletics on academic performance among high school sophomores and juniors (Doctoral dissertation).

Stephens, L. J., \& Schaben, L. A. (2002). The effect of interscholastic sports participation on academic achievement of middle level school students. Nassp Bulletin, 86(630), 34-41. https://doi.org/10.1177/019263650208663005

Zajacova, A., Lynch, S. M., \& Espenshade, T. J. (2005). Self-efficacy, stress, and academic success in college. Research in higher education, 46(6), 677-706. https://doi.org/10.1007/s11162-004-4139-z

\section{Copyrights}

Copyright for this article is retained by the author(s), with first publication rights granted to the journal.

This is an open-access article distributed under the terms and conditions of the Creative Commons Attribution license (http://creativecommons.org/licenses/by/4.0/). 